\begin{tabular}{|l|l|}
\hline Postprint Version & 1.0 \\
\hline Journal website & $\underline{\text { http://dx.doi.org/10.1016/j.pec.2011.01.017 }}$ \\
\hline Pubmed link & $\underline{\text { http://www.ncbi.nlm.nih.gov/pubmed/21316181 }}$ \\
\hline DOI & $10.1016 /$ j.pec.2011.01.017 \\
\hline
\end{tabular}

\title{
Longer-term influence of breast cancer genetic counseling on cognitions and distress: Smaller benefits for affected versus unaffected women
}

\author{
Arwen H. Pieterse ${ }^{A}$, Margreet G.e.M. Ausems ${ }^{B}$, Peter SpreeuWenberg $^{\mathrm{C}}$ and Sandra van \\ DULMEN ${ }^{\mathrm{C}}$ \\ ${ }^{a}$ Department of Medical Decision Making, Leiden University Medical Centre, Leiden, The Netherlands \\ ${ }^{\mathrm{b}}$ Department of Medical Genetics, University Medical Centre Utrecht, Utrecht, The Netherlands \\ ${ }^{c}$ Netherlands Institute for Health Services Research (NIVEL), Utrecht, The Netherlands
}

\begin{abstract}
Objective: To evaluate outcomes of breast cancer genetic counseling in women with and without breast cancer.

Methods: Seventy-seven first-time attendees $(n=44$ affected) completed questionnaires assessing cognitions (risk accuracy, knowledge, perceived personal control [PPC]) and distress (state anxiety [STAI], cancer-related stress reactions [IES]) from immediately before to immediately and six months after completing counseling. Data were analyzed using multilevel repeated measures and trend analyses.

Results: In affected counselees, mean cognitions did not significantly differ over time, anxiety significantly decreased, and IES levels were increased immediately post-counseling. In unaffected counselees, cognitions significantly improved over time except for knowledge. Distress levels showed similar patterns as in affected women. Improvements in cognitions and distress were significantly smaller in affected versus unaffected women.

Conclusion: Overall, counseling educates women about breast cancer risk and alleviates their anxiety. Importantly, benefits gained at immediate follow-up seem maintained over time.

Practice implication: Affected women seem to benefit less from counseling. Counselors may need to devote more effort into educating these women and addressing their anxieties. Future studies should confirm the unexpected finding that cancer-related distress increased immediately post-counseling.
\end{abstract}

\section{INTRODUCTION}

A main goal of breast cancer genetic counseling is to educate individuals about their cancer risk in ways that increase personal control and minimize psychological distress [1] B.B. Biesecker, Goals of genetic counseling, Clin Genet 60 (2001), pp. 323-330. View Record in Scopus | Cited By in Scopus (54)[1]. A challenge in informing counselees about their personal and family members' cancer risk is that diagnostic DNA-testing of the BRCA1/2 genes often does not identify a mutation [2]. The pedigree alone then guides breast cancer risk estimations, which then remain less precise. Also, counselees frequently overestimate breast cancer risk after DNA-testing [3] and [4].

The aim of genetic counseling is to improve counselees' knowledge about their genetic condition and help them cope with it [5]. These goals are relevant both for counselees who are and who are not affected by 
Pieterse, A.H., Ausems, M.G.E.M., Spreeuwenberg, P., Dulmen, S. van. Longer-term influence of breast cancer genetic counseling on cognitions and distress: smaller benefits for affected versus unaffected women. Patient Education and Counseling: 2011, 85(3), 425-431

cancer themselves. Yet, women already affected by breast cancer may consider counseling less relevant for them personally. It is therefore important to distinguish affected from unaffected women when examining the impact of counseling. With few exceptions [6] and [7], such comparisons have usually not been reported. Another limitation of studies to date is the variety in content of counseling and lack of clarity as to whether available genetic test results and appropriate recommendations regarding risk management had been communicated. Indeed, breast cancer genetic counseling may include any intervention aimed at informing counselees about breast cancer genetics and risk, advising about breast cancer risk management options, or assisting counselees in psychologically adjusting to distress caused by their breast cancer risk. In order to assess the impact of counseling, it is relevant to evaluate its outcome after it has been completed.

In unaffected women with a family history of breast cancer, prospective studies have demonstrated improvements in cognitions and distress from before to after counseling. Specifically, risk perception accuracy was more frequent shortly after (i.e., up to one month) versus before counseling, even though overestimations persisted [8], [9], [10] and [11]. Similar improvements were found with follow-up periods up to one year [9], [11], [12] and [13], even though not unequivocally [13]. Improved knowledge about breast cancer genetics was found at one-year follow-up [14]. Lower state anxiety levels were found at immediate follow-up, compared to baseline [8], [9], [10] and [15]. At one-year follow-up, lowered levels were not reported [7] and [14]. Some studies have shown reductions in cancer-specific distress at one-year follow-up [7] and [13] while others did not detect differences [9]. Overall, unaffected women appear to accommodate well to learning about their risk status [3] and [4].

Much less is known about changes in cognitions and distress in affected women seeking breast cancer genetic counseling. Both risk perception accuracy [16] and psychological effects of counseling [7] and [17] for affected individuals are underreported. Randall et al. [18] reported no improvement in knowledge about genetic testing up to six months post-counseling. Few studies compared changes in cognitions and distress following counseling between affected and unaffected women. MacDonald et al. [6] reported affected versus unaffected women to believe they were at lower risk for breast cancer, and to rate family history less often as a personal risk. Evidence further does not suggest group differences in state anxiety or cancerspecific distress [7]. A larger number of studies include women affected by breast and/or ovarian cancer. For example, Wood et al. [19] reported lower anxiety one month after test result disclosure in women with a personal cancer history. No differences were found in the course of perceived risk from baseline to sixmonth post-counseling [20], or of general anxiety or cancer-related distress from baseline to two-week [21] to six-month [20] post-counseling.

This study aims to assess (a) changes in cognitions (accurate risk perception, correct knowledge, perceived personal control) and distress (state anxiety, cancer-related stress reactions) from before to immediately and six months after concluding breast cancer genetic counseling in female counselees, and (b) whether changes in cognitions and distress were similar in affected versus unaffected women.

\section{METHODS}

\subsection{Design}

We undertook secondary analyses of data recruited as part of a larger study on need fulfillment and communication during initial cancer genetic counseling visits [22].

\subsection{Participants}

Eleven counselors (clinical geneticists, residents in clinical genetics, and genetic counselors) providing cancer genetic counseling at the Department of Medical Genetics of the University Medical Centre Utrecht, the Netherlands, were invited and agreed to participate in the larger study. Counselees were eligible if they sought counseling for hereditary cancer, were the first among their first- and second-degree relatives to request counseling, were first-time attendees, and were aged 18 years or older. In the larger study 204/622 $(33 \%)$ of eligible counselees agreed to participate. These 204 counselees were on average 2.1 years older than decliners $(\mathrm{p}=0.022)$ but did not differ regarding gender, referral path, cancer type, or (family) history of cancer [23]. Counselees had been referred most frequently for breast/ovarian or colon cancer counseling, and visited the department between March 2001 and August 2003. Purposive sampling of women affected by breast cancer or with no personal history of cancer who sought counseling for breast cancer was performed for the present analyses. 
Pieterse, A.H., Ausems, M.G.E.M., Spreeuwenberg, P., Dulmen, S. van. Longer-term influence of breast cancer genetic counseling on cognitions and distress: smaller benefits for affected versus unaffected women. Patient Education and Counseling: 2011, 85(3), 425-431

\subsection{Procedure}

The institutional Medical Ethical Committee approved the larger study. The procedure of approaching eligible counselees is described elsewhere [23]. Counselees were asked to complete an informed consent form and a pre-counseling questionnaire assessing socio-demographics and family history of cancer, in the week before their first consultation $\left(\mathrm{T}_{0}\right)$. Counselors handed out a post-counseling questionnaire together with a stamped envelope immediately after the last consultation $\left(\mathrm{T}_{1}\right)$, and asked counselees to complete it within a day and to send it to the research institute. Six months after $T_{1}\left(T_{2}\right)$ counselees were sent a followup questionnaire. A reminder was sent if this questionnaire was not returned within a month. Cognitions and distress were assessed at $\mathrm{T}_{0}, \mathrm{~T}_{1}$ and $\mathrm{T}_{2}$. Counselors completed a questionnaire after counselees' last visit. Box 1 details the counseling procedure, which applied to all counselees.

Box 1. Genetic counseling for suspected hereditary breast cancer.

Breast cancer genetic counseling is offered to affected women and to healthy individuals having multiple affected relatives. Topics discussed during the first visit include occurrence of breast and other cancers in the family, inheritance in general, and criteria indicating increased probability of hereditary breast cancer. The likelihood that hereditary breast cancer runs in the family is estimated based on characteristics of the patient (e.g. age at diagnosis, bilateral breast cancer and other cancers) and on family characteristics (number of relatives affected with breast or ovarian cancer and age at diagnosis). Genetic testing is offered to a subset of counselees or their affected relatives only when they have an a priori chance $\geq 10 \%$ of carrying a BRCA1/2-mutation [45]. Counselees who are eligible for BRCA1/2 testing are informed about the possible medical consequences of carrying a BRCA mutation, e.g. highly elevated risk on contralateral breast cancer and ovarian cancer, and on options regarding surveillance and risk reducing surgery [46]. In about $15 \%$ of tested patients only, results show a pathogenic BRCA1/2-mutation [47]. In the majority, no mutation (uninformative test result) or an 'unclassified variant' is detected. Breast cancer risk estimations are based on conclusive BRCA1/2-test results [46] or on the pedigree [48], in case BRCA1/2-testing was uninformative or not conducted. Periodic breast surveillance is recommended to all counselees at increased risk $(>20 \%)$. Their surveillance program depends on the height of the risk [49]. All counselees and the referring physician receive a summary letter of the genetic and risk information that was given.

\subsection{Measures}

Disease status, BRCA1/2-test indication, and DNA-test result were collected from counselees' medical file. Outcome measures included counselees' risk perception accuracy, correct knowledge, perceived personal control, generalized state anxiety and cancer-related distress.

Counselees' risk perception accuracy was determined by comparing their perceived lifetime risk of developing or redeveloping breast cancer to the counselor's perception of that risk for the counselee. Counselees' and counselors' perceptions were assessed using a visual analogue scale with endpoints labeled $0 \%$ and $100 \%$.

Correct knowledge about hereditary breast cancer was assessed using seven items (correct, incorrect, don't know) adapted from Claes et al. [24] and [25]. The items covered probabilities of carrying a BRCA1/2mutation and of developing breast cancer conditional on carrier status, and the necessity of surveillance. Total correct knowledge scores (range, $0-7$ ) were calculated as the number of correct answers. Higher scores indicate more correct knowledge.

Perceived personal control, i.e., beliefs regarding control over the threat of hereditary increased risk were assessed using the nine-item Perceived Personal Control questionnaire (PPC) [26] and [27]. Internal consistencies were high $\left(\alpha \mathrm{T}_{0}=0.80 ; \alpha \mathrm{T}_{1}=0.85 ; \alpha \mathrm{T}_{2}=0.83\right)$. Higher mean total scores (range, $\left.0-2\right)$ represent higher perceived control.

Generalized state anxiety was measured with the ten-item State-Trait Anxiety Inventory (STAI) [28] and [29]. Internal consistencies were high $\left(\alpha \mathrm{T}_{0}=0.93 ; \alpha \mathrm{T}_{1}=0.95 ; \alpha \mathrm{T}_{2}=0.96\right)$. Higher scores (range, 10-40) indicate greater anxiety. Scores $>22$ have been used to indicate high anxiety in women aged 40-59 [30], and in women diagnosed with breast [31] or cervical [32] cancer.

Cancer-related distress was measured with the Impact of Events Scale (IES) [33] and [34], rating intrusive (seven items) and avoidant (eight items) thinking relating to 'seeking genetic counseling for hereditary cancer'. We used the total IES scores. Internal consistencies were high $\left(\alpha \mathrm{T}_{0}=0.85 ; \alpha \mathrm{T}_{1}=0.89 ; \alpha \mathrm{T}_{2}=0.91\right)$. Higher scores (range, $0-75$ ) indicate more distress. Scores of 9-25 and $>26$ are indicative of, respectively, moderate and clinical adaptation difficulties [17] and [35]. 
Pieterse, A.H., Ausems, M.G.E.M., Spreeuwenberg, P., Dulmen, S. van. Longer-term influence of breast cancer genetic counseling on cognitions and distress: smaller benefits for affected versus unaffected women. Patient Education and Counseling: 2011, 85(3), 425-431

\subsection{Statistical analyses}

Missing PPC, STAI and IES values were replaced by the mean of the scale if $\leq 25 \%$ were missing. We defined counselee risk perception accuracy as the correct counseled risk [36]. Because of few occurrences per category (Table 1), under-estimators and accurate estimators were collapsed into $0=$ 'close estimation' versus $1=$ 'overestimation'. Counselees who did versus did not return the $\mathrm{T}_{2}$ questionnaire and affected versus unaffected counselees with complete data were compared on age, educational level, personal and family history of cancer, BRCA1/2-test indication, breast cancer risk estimation, and levels of precounseling measures using chi-square, Mann-Whitney, and t-tests. The latter groups were further compared on total number of visits, and those tested on outcome of DNA-testing.

\section{[TABLE 1]}

Multilevel repeated measures analysis was conducted to assess changes in PPC, STAI and IES over time, and to compare scores and score differences between groups. Risk accuracy was analyzed using multilevel logistic regression analysis, and correct knowledge was analyzed as count data using Poisson multilevel regression analysis. Additionally, we assessed whether outcome measures showed significant linear and/or quadratic trends over time. The multilevel models used counselor as the highest level and afforded control for counselee intra-individual correlations between outcome measures. Analyses were further controlled for variables on which affected and unaffected counselees significantly differed, which centred on the mean in the sample.

Analyses were carried out using SPSS 16.0 and MLwiN 2.02. Significance was tested two-sided at $\alpha=0.05$.

\section{RESULTS}

\subsection{Participants}

Of the 204 counselees in the larger study, 127 (62\%) were women requesting counseling for breast cancer, and 77/127 (61\%) returned the three questionnaires. These 77 counselees constitute the present sample. They did not significantly differ from the 50 counselees who did not return the $\mathrm{T}_{2}$ questionnaire.

Counselees were 44 years on average (SD $=9.3$; range, $18-64)$ and $28(36 \%)$ had completed higher vocational education or university. Counseling consisted of one $(n=24$ counselees, $31 \%)$, two $(n=48$, $62 \%)$, three $(\mathrm{n}=4,5 \%)$, or four $(\mathrm{n}=1,1 \%)$ visits. Time between $\mathrm{T}_{0}$ and $\mathrm{T}_{2}$ varied between 6 and 24 $(\mathrm{Md}=11)$ months, depending on the number of visits. Counselors each saw between 2 and $16(\mathrm{Md}=7)$ counselees.

Table 1 lists counselees' breast cancer risk-related characteristics by disease status and overall. Counselees had $0-4(\mathrm{Md}=1)$ first-degree and $0-8(\mathrm{Md}=1)$ second-degree affected relatives. Affected versus unaffected counselees had significantly less first-degree affected relatives $(M d=0$ vs $1, p=0.007)$, more often an indication for DNA-testing $(\mathrm{p}<0.001)$, and more visits $(\mathrm{Md}=2 \mathrm{vs} 1, \mathrm{p}=0.044)$. Moreover, less affected than unaffected counselees overestimated their risk $\left(75 \%\right.$ vs $\left.97 \% ; \chi^{2}=6.08, p=0.02\right)$. Precounseling $30(39 \%)$ women could be classified as highly anxious and $20(27 \%)$ as having clinical adaptation difficulties. Half of them (respectively, $57 \%$ and $55 \%$ ) were affected.

\subsection{Overall changes in cognitions and distress over time}

Table 1 shows the number of counselees who closely estimated versus over-estimated their risk from $T_{0}$ to $T_{2}$. Mean levels of risk accuracy and perceived control were significantly higher at $T_{1}$ and $T_{2}$, versus $T_{0}$ (Table 2). Mean levels of correct knowledge did not significantly change over time. Half of the counselees completed $\geq 5 / 7(70 \%)$ knowledge items correctly $\left(44 / 77,57 \%\right.$ at $\mathrm{T}_{0}$ and $40 / 77,52 \%$ at both $\mathrm{T}_{1}$ and $\left.\mathrm{T}_{2}\right)$. Mean levels of cognitions did not significantly differ between $\mathrm{T}_{1}$ and $\mathrm{T}_{2}$ (Table 2).

\section{[TABLE 2]}

Risk perception accuracy showed a significant linear $\left(\chi^{2}=7.73, \mathrm{p}<0.01\right)$ and quadratic $\left(\chi^{2}=10.53\right.$, $\mathrm{p}<0.01)$ trend; increase in mean risk perception accuracy between $\mathrm{T}_{0}$ and $\mathrm{T}_{1}$ was larger than its decrease between $T_{1}$ and $T_{2}$. Perceptions of control showed a significant linear increase $\left(\chi^{2}=12.56, p<0.001\right)$. 
Pieterse, A.H., Ausems, M.G.E.M., Spreeuwenberg, P., Dulmen, S. van. Longer-term influence of breast cancer genetic counseling on cognitions and distress: smaller benefits for affected versus unaffected women. Patient Education and Counseling: 2011, 85(3), 425-431

Mean level of state anxiety was significantly lower at $T_{1}$ and $T_{2}$ versus $T_{0}$, and at $T_{2}$ compared to $T_{1}$ (Table 2). Twenty-three $\left(\mathrm{T}_{1}\right)$ and $15\left(\mathrm{~T}_{2}\right)$ counselees were highly anxious at follow-up. Mean IES level was significantly higher at $\mathrm{T}_{1}$ versus $\mathrm{T}_{0}$. Twenty-seven $(36 \%)$ and $19(26 \%)$ counselees had clinical difficulties in adapting at $T_{1}$ and $T_{2}$, respectively. State anxiety showed a significant $\left(\chi^{2}=26.74, p<0.001\right)$ linear decrease. IES scores showed a significant $\left(\chi^{2}=4.38, \mathrm{p}<0.05\right)$ quadratic trend, with similar levels at $\mathrm{T}_{0}$ and $\mathrm{T}_{2}$ and higher levels at $\mathrm{T}_{1}$.

\subsection{Changes in cognitions and distress over time in affected versus unaffected counselees}

Patterns of cognitions and distress levels significantly differed between affected and unaffected counselees (Table 3). Specifically, mean levels of cognitions did not significantly differ over time in affected counselees. In contrast, in unaffected counselees mean risk accuracy was significantly higher at $\mathrm{T}_{1}$ and $\mathrm{T}_{2}$ versus $\mathrm{T}_{0}$ and showed similar significant linear $\left(\chi^{2}=11.80, \mathrm{p}<0.001\right)$ and quadratic $\left(\chi^{2}=9.39, \mathrm{p}<0.01\right)$ trends as in the overall sample. The increase in mean accuracy between $\mathrm{T}_{0}-\mathrm{T}_{1}$ and $\mathrm{T}_{0}-\mathrm{T}_{2}$ was significantly smaller in affected versus unaffected counselees (Fig. 1). Twenty-one (66\%) affected and 11 (34\%) unaffected women persisted in their overestimation from $\mathrm{T}_{0}$ to $\mathrm{T}_{2}$.

\section{[TABLE 3]}

\section{[FIGURE 1]}

In unaffected counselees, mean levels of correct knowledge were significantly lower at $T_{2}$ versus $T_{0}$, and showed a significant $\left(\chi^{2}=4.34, \mathrm{p}<0.05\right)$ linear decrease. Of those completing $\geq 5 / 7$ items correctly, 26 $(60 \%)$ and $28(70 \%)$ were affected, respectively. In the same group, mean levels of perceived control were significantly higher at $T_{1}$ and $T_{2}$ versus $T_{0}$ and showed a significant $\left(\chi^{2}=14.22, p<0.001\right)$ linear increase.

In affected counselees, mean levels of state anxiety were significantly lower at $T_{2}$ versus $T_{0}$. In unaffected counselees, anxiety levels were significantly lower at $T_{1}$ and $T_{2}$ versus $T_{0}$. State anxiety showed significant linear decreases both in affected $\left(\chi^{2}=7.20, p<0.01\right)$ and in unaffected $\left(\chi^{2}=24.88, p<0.001\right)$ counselees. The decrease in mean anxiety levels between $\mathrm{T}_{0}$ and $\mathrm{T}_{2}$ was significantly smaller in affected versus unaffected counselees (Fig. 2). At $\mathrm{T}_{1}$ and $\mathrm{T}_{2}$, respectively, 14/23 (61\%) and 11/15 (73\%) of highly anxious counselees were affected. Ten counselees were highly anxious from $T_{0}$ to $T_{2}$, of whom $6(60 \%)$ were affected.

\section{[FIGURE 2]}

In affected counselees, mean IES scores were significantly higher at $\mathrm{T}_{1}$ versus $\mathrm{T}_{0}$, and scores showed a significant $\left(\chi^{2}=3.95, p<0.05\right)$ quadratic trend with similar levels at $\mathrm{T}_{0}$ and $\mathrm{T}_{2}$ and higher levels at $\mathrm{T}_{1}$. The decrease in mean IES scores was significantly smaller in affected versus unaffected counselees from $\mathrm{T}_{0}$ to $\mathrm{T}_{2}$ (Fig. 2). At $\mathrm{T}_{1}$ and $\mathrm{T}_{2}$, respectively, 19/27 (70\%) and 15/19 (79\%) counselees with clinical difficulties in adapting were affected. Thirteen counselees had those difficulties from $\mathrm{T}_{0}$ to $\mathrm{T}_{2}$, of whom $9(69 \%)$ were affected.

\section{DISCUSSION AND CONCLUSION}

\subsection{Discussion}

A primary informational motive to seek genetic counseling in families with no known mutation is to learn about one's own and/or family members' cancer risk [23], [37] and [38]. In the present sample of women requesting counseling for hereditary breast cancer, risk perceptions appeared more accurate following counseling. However, a majority of women overestimated their risk at immediate and six-month follow-up, and a large minority (44\%) persisted in their overestimation from baseline to follow-up. Women may often not learn estimates of their personal cancer risk during counseling [39]. Efforts to convey the best estimate possible may help them in developing more accurate perceptions.

Counselees seemed to perceive more control over their situation following counseling, a result extending results found in counselees for various cancers after the initial visit [25]. Importantly, levels of perceived control at immediate follow-up seemed maintained over time. Higher perception of control may help counselees in adapting to their situation and was related to better fulfillment of pre-counseling needs after the initial visit [25]. 
Pieterse, A.H., Ausems, M.G.E.M., Spreeuwenberg, P., Dulmen, S. van. Longer-term influence of breast cancer genetic counseling on cognitions and distress: smaller benefits for affected versus unaffected women. Patient Education and Counseling: 2011, 85(3), 425-431

Surprisingly, levels of correct knowledge about hereditary breast cancer did not appear to improve over time. Only half of the women responded correctly to a majority of the knowledge items pre-counseling and six months after completing counseling. The items covered topics discussed during counseling (Box 1). Yet, the information may have been inadequate in terms of amount, format, or content. Providing more medical information may improve counselees' knowledge [40], but may fail to do so [41]. Alternatively, encouraging participants to systematically 'pre-live' possible genetic testing scenarios and to anticipate their reactions to each potential outcome, may benefit learning [42]. More generally, in order to educate effectively counselors should take time to review women's existing knowledge about hereditary cancer and DNA-testing to assess women's understanding. Only then can they add to the women's body of knowledge in ways that they can better integrate the newly acquired information [43]. In the present study, genetic information that counselees deem relevant may not have been given. The findings warrant more research on what information the professional body considers essential for counselees to learn, what information women are seeking, and on how to get essential information better across.

Overall, counseling appeared to lower counselees' generalized anxiety, and lower anxiety levels at immediate follow-up were further lowered over time. Distress related to visiting the genetic centre seemed heightened at immediate follow-up but returned to pre-counseling levels over time. This result is comparable to findings on distress related to developing breast cancer [9].

Remarkably, the cognitive and emotional benefits of counseling did not appear to be equally achieved for affected versus unaffected counselees. Our results suggest that especially unaffected counselees profit from counseling. Counseling did not seem to educate affected women about their breast cancer risk, possibly because of their personal experience. Of note, affected versus unaffected women less often overestimated their breast cancer risk pre-counseling. One possible explanation for the present findings is that affected women may learn less often about their personal risk during counseling. In an earlier analysis among 51 women seeking hereditary breast/ovarian counseling, we found that counselors told only $38 \%$ affected versus $82 \%$ unaffected women a personalized lifetime risk [39]. Moreover, we found affected versus unaffected counselees for various types of cancer to consider information about their own cancer risk as less important [22]. Thus, apart from difficulties in estimating lifetime risks of redeveloping cancer, especially in women with no known BRCA1/2-mutation [44], affected versus unaffected women may learn less often about their personal risk because they do not ask for that information.

In contrast, unaffected women reported even lower levels of correct knowledge following counseling compared to affected women. These results confirm earlier findings in affected women [18] but contradict findings in unaffected women [14]. It is unclear how these results should be explained, especially since they challenge our earlier results following the initial visit [25]. Possibly, the scale Meiser et al. [14] used asked more specifically about information that had actually been given during counseling.

Both affected and unaffected women reported lower levels of anxiety at follow-up, but decrease in anxiety seemed stronger in unaffected women. Since we controlled the present analyses for BRCA1/2-test indication, higher rates of indication for testing in affected compared to unaffected women cannot explain differences in changes in anxiety from before to after the initial visit. Also, counselors' estimates of lifetime breast cancer risk did not differ between affected and unaffected counselees. More research is needed to gain insight into these differences. Affected counselees experienced a peak in cancer-related distress immediately post-counseling. Possibly, this resulted from having processed the information counselees just received, which included results of DNA-testing more often than for unaffected counselees. A significant minority of women was either highly anxious, had clinical difficulties in adapting, or both, from before to six months after completing counseling. Ways to improve emotional support for highly distressed women should be investigated. Counselors need to pay attention to women displaying high distress at the start of counseling. These women are vulnerable to long-term high distress, as was also found in women who had been approached for genetic counseling shortly after their breast cancer diagnosis [17].

Limitations of this study should be noted. The relatively small sample size, the fact that the data were gathered a couple of years ago, and at a single genetic centre, constrain the generalisability of the results. The low response rate in the larger study may have been due to study requirements [23]. Specifically, we asked eligible counselees to put effort into indicating their willingness to participate, by returning a reply slip. These were secondary analyses and the sample might have been too small to show significant differences, especially by disease status. A significant minority of participants did not complete all three questionnaires, however did not differ on baseline measures from those with complete data. We are not 
Pieterse, A.H., Ausems, M.G.E.M., Spreeuwenberg, P., Dulmen, S. van. Longer-term influence of breast cancer genetic counseling on cognitions and distress: smaller benefits for affected versus unaffected women. Patient Education and Counseling: 2011, 85(3), 425-431

aware of important changes in the provision of counseling for hereditary breast cancer since the data were collected. Screening recommendations have changed though; thresholds for recommending intensive surveillance to unaffected women have been lowered, which may increase their distress. Moreover, a longer follow-up period is necessary to evaluate whether the findings hold over time.

\subsection{Conclusion}

Our results confirm that counseling is beneficial in educating women about lifetime breast cancer risk overall. However, correct knowledge about breast cancer genetics lowered over time, asking for better ways to get across essential and relevant information. Moreover, more attention seems warranted in counseling affected women, as a large minority persisted in overestimating their risk. Also, affected women remained more often at pre-counseling levels of anxiety compared to unaffected women. Since half of the affected women were highly anxious, these findings call for a careful assessment of how to provide them with emotional support. Importantly, benefits gained immediately following counseling seem to be maintained over longer time periods.

\subsection{Practice implication}

The present results suggest that counselors may need to adapt their consultations more to individual counselees' breast cancer status, since counseling seems to act differently on affected and unaffected women. In particular, the unexpected increase we detected in scores on the IES of affected women suggests that counseling reinforces the negative burden of the disease for affected counselees. Counselors should be made aware of this and discuss it during the final counseling session. More effort may need to be devoted to addressing affected women's potential distress more generally. Counselors may do so either by devoting more time on addressing anxieties during the visit, or by offering more often to refer highly anxious women to a specialized nurse or social worker for emotional support.

\section{ACKNOWLEDGEMENTS}

We thank the participating counselees and counselors for their efforts during the study period. The Dutch Cancer Society supported the original study (grant number NIVEL 1999-2090). Arwen Pieterse is supported by a postdoctoral fellowship from the Dutch Cancer Society.

\section{REFERENCES}

[1] B.B. Biesecker, Goals of genetic counseling, Clin Genet 60 (2001), pp. 323-330.

[2] K.L. Nathanson, R. Wooster and B.L. Weber, Breast cancer genetics: what we know and what we need, Nat Med 7 (2001), pp. 552-556.

[3] B. Meiser and J.L. Halliday, What is the impact of genetic counselling in women at increased risk of developing hereditary breast cancer? A meta-analytic review, Soc Sci Med 54 (2002), pp. 1463-1470.

[4] P.N. Butow, E.A. Lobb, B. Meiser, A. Barratt and K.M. Tucker, Psychological outcomes and risk perception after genetic testing and counselling in breast cancer: a systematic review, Med J Australia 178 (2003), pp. 77-81.

[5] C. Wang, R. Gonzalez, K.J. Milliron, V.J. Strecher and S.D. Merajver, Genetic counseling for BRCA1/2: a randomized controlled trial of two strategies to facilitate the education and counseling process, Am J Med Genet A 134A (2005), pp. 66-73.

[6] D.J. MacDonald, L. Sarna, G.C. Uman, M. Grant and J.N. Weitzel, Health beliefs of women with and without breast cancer seeking genetic cancer risk assessment, Cancer Nurs 28 (2005), pp. 372-379.

[7] A. Bish, S. Sutton, C. Jacobs, S. Levene, A. Ramirez and S. Hodgson, Changes in psychological distress after cancer genetic counselling: a comparison of affected and unaffected women, Brit J Cancer 86 (2002), pp. 43-50.

[8] A. Cull, H. Miller, T. Porterfield, J. Mackay, E.D. Anderson and C.M. Steel et al., The use of videotaped information in cancer genetic counselling: a randomized evaluation study, Brit J Cancer 77 (1998), pp. 830-837.

[9] M. Watson, S. Lloyd, J. Davidson, L. Meyer, R. Eeles and S. Ebbs et al., The impact of genetic counselling on risk perception and mental health in women with a family history of breast cancer, Brit $\mathrm{J}$ Cancer 79 (1999), pp. 868-874.

[10] A. Cull, E.D. Anderson, S. Campbell, J. Mackay, E. Smyth and M. Steel, The impact of genetic counselling about breast cancer risk on women's risk perceptions and levels of distress, Brit J Cancer 79 (1999), pp. 501-508. 
Pieterse, A.H., Ausems, M.G.E.M., Spreeuwenberg, P., Dulmen, S. van. Longer-term influence of breast cancer genetic counseling on cognitions and distress: smaller benefits for affected versus unaffected women. Patient Education and Counseling: 2011, 85(3), 425-431

[11] E.A. Lobb, P.N. Butow, B. Meiser, A. Barratt, C. Gaff and M.A. Young et al., Women's preferences and consultants' communication of risk in consultations about familial breast cancer: impact on patient outcomes, J Med Genet 40 (2003), p. e56.

[12] D.G. Evans, V. Blair, R. Greenhalgh, P. Hopwood and A. Howell, The impact of genetic counselling on risk perception in women with a family history of breast cancer, Brit J Cancer 70 (1994), pp. 934-938.

[13] B. Meiser, P. Butow, A. Barratt, M. Gattas, C. Gaff and E. Haan et al., Risk perceptions and knowledge of breast cancer genetics in women at increased risk of developing hereditary breast cancer, Psychol Health 16 (2001), pp. 297-311.

[14] B. Meiser, P.N. Butow, A.L. Barratt, V. Schnieden, M. Gattas and J. Kirk et al., Long-term outcomes of genetic counseling in women at increased risk of developing hereditary breast cancer, Patient Educ Couns 44 (2001), pp. 215-225.

[15] C. Julian-reynier, F. Eisinger, F. Chabal, Y. Aurran, Y.J. Bignon and M. Helard-roumagnac et al., Cancer genetic consultation and anxiety in healthy consultees, Psychol Health 14 (1999), pp. 379-390.

[16] S. van Dijk, D.R. Timmermans, H. Meijers-Heijboer, A. Tibben, C.J. van Asperen and W. Otten, Clinical characteristics affect the impact of an uninformative DNA test result: the course of worry and distress experienced by women who apply for genetic testing for breast cancer, J Clin Oncol 24 (2006), pp. 36723677.

[17] K.J. Schlich-Bakker, M.G. Ausems, M. Schipper, H.F. Ten Kroode, C.C. Warlam-Rodenhuis and J. van den Bout, BRCA1/2 mutation testing in breast cancer patients: a prospective study of the long-term psychological impact of approach during adjuvant radiotherapy, Breast Cancer Res $\operatorname{Tr} 109$ (2008), pp. 507-514.

[18] J. Randall, P. Butow, J. Kirk and K. Tucker, Psychological impact of genetic counselling and testing in women previously diagnosed with breast cancer, Intern Med J 31 (2001), pp. 397-405.

[19] M.E. Wood, L. Mullineaux, A.K. Rahm, D. Fairclough and L. Wenzel, Impact of BRCA1 testing on women with cancer: a pilot study, Genet Test 4 (2000), pp. 265-272.

[20] A.W. Smith, A.L. Dougall, D.M. Posluszny, T.J. Somers, W.S. Rubinstein and A. Baum, Psychological distress and quality of life associated with genetic testing for breast cancer risk, Psychooncology 17 (2008), pp. 767-773.

[21] M.S. van Roosmalen, P.F. Stalmeier, L.C. Verhoef, J.E. Hoekstra-Weebers, J.C. Oosterwijk and N. Hoogerbrugge et al., Impact of BRCA1/2 testing and disclosure of a positive test result on women affected and unaffected with breast or ovarian cancer, Am J Med Genet A 124A (2004), pp. 346-355.

[22] A.H. Pieterse, A.M. van Dulmen, M.G. Ausems, F.A. Beemer and J.M. Bensing, Communication in cancer genetic counselling: does it reflect counselees' previsit needs and preferences, Brit J Cancer 92 (2005), pp. 1671-1678.

[23] A. Pieterse, S. van Dulmen, M. Ausems, A. Schoemaker, F. Beemer and J. Bensing, QUOTEgene(ca): development of a counselee-centered instrument to measure needs and preferences in genetic counseling for hereditary cancer, Psychooncology 14 (2005), pp. 361-375.

[24] E. Claes, G. Evers-Kiebooms, A. Boogaerts, M. Decruyenaere, L. Denayer and E. Legius, Communication with close and distant relatives in the context of genetic testing for hereditary breast and ovarian cancer in cancer patients, Am J Med Genet A 116A (2003), pp. 11-19.

[25] A.H. Pieterse, M.G. Ausems, A.M. van Dulmen, F.A. Beemer and J.M. Bensing, Initial cancer genetic counseling consultation: change in counselees' cognitions and anxiety, and association with addressing their needs and preferences, Am J Med Genet A 137 (2005), pp. 27-35.

[26] M. Berkenstadt, S. Shiloh, G. Barkai, M.B. Katznelson and B. Goldman, Perceived personal control (PPC): a new concept in measuring outcome of genetic counseling, Am J Med Genet 82 (1999), pp. 5359.

[27] E.M. Smets, A.H. Pieterse, C.M. Aalfs, M.G. Ausems and A.M. van Dulmen, The perceived personal control (PPC) questionnaire as an outcome of genetic counseling: reliability and validity of the instrument, Am J Med Genet A 140 (2006), pp. 843-850.

[28] C. Spielberger, R.L. Gorsuch, R.E. Lushene, P.R. Vagg and G.A. Jacobs, Manual of the state-trait anxiety inventory, Consulting Psychologists Press, Palo Alto, CA (1983).

[29] H. van der Ploeg, P. Defares and C. Spielberger, Handleiding bij de Zelfbeoordelings Vragenlijst (ZBV) [Manual of the Dutch version of the State Trait Anxiety Inventory], Swets and Zeitlinger, Lisse, The Netherlands (1980).

[30] C. Spielberger and R.L. Gorsuch, STAI manual, Consulting Psychologists Press, Palo Alto, CA (1970).

[31] K. Millar, M. Jelicic, B. Bonke and A.J. Asbury, Assessment of preoperative anxiety: comparison of measures in patients awaiting surgery for breast cancer, Brit J Anaesth 74 (1995), pp. 180-183.

[32] I.J. Korfage, M.L. Essink-Bot, F. Mols, L. van de Poll-Franse, R. Kruitwagen and M. van Ballegooijen, Health-related quality of life in cervical cancer survivors: a population-based survey, Int J Radiat Oncol Biol Phys 73 (2009), pp. 1501-1509. 
Pieterse, A.H., Ausems, M.G.E.M., Spreeuwenberg, P., Dulmen, S. van. Longer-term influence of breast cancer genetic counseling on cognitions and distress: smaller benefits for affected versus unaffected women. Patient Education and Counseling: 2011, 85(3), 425-431

[33] M. Horowitz, N. Wilner and W. Alvarez, Impact of event scale: a measure of subjective stress, Psychosom Med 41 (1979), pp. 209-218.

[34] D. Brom and R.J. Kleber, De Schok Verwerkingslijst [The Dutch impact of event scale], Ned Tijdschr Psychol 40 (1985), pp. 164-168.

[35] M.J. Horowitz, Stress response syndromes and their treatment. In: L. Goldenberger and S. Breznitz, Editors, Handbook of stress: theoretical and clinical aspects, Free Press, New York (1982), pp. 711-732.

[36] C.M. Smerecnik, I. Mesters, E. Verweij, N.K. de Vries and V.H. de, A systematic review of the impact of genetic counseling on risk perception accuracy, J Genet Couns 18 (2009), pp. 217-228.

[37] K. Brain, J. Gray, P. Norman, E. Parsons, A. Clarke and C. Rogers et al., Why do women attend familial breast cancer clinics, J Med Genet 37 (2000), pp. 197-202.

[38] C.J. van Asperen, S. van Dijk, M.W. Zoeteweij, D.R. Timmermans, G.H. De Bock and E.J. MeijersHeijboer et al., What do women really want to know? Motives for attending familial breast cancer clinics, $\mathrm{J}$ Med Genet 39 (2002), pp. 410-414.

[39] A.H. Pieterse, S. van Dulmen, S. van Dijk, J.M. Bensing and M.G. Ausems, Risk communication in completed series of breast cancer genetic counseling visits, Genet Med 8 (2006), pp. 688-696.

[40] A.H. Pieterse, A.M. van Dulmen, F.A. Beemer, J.M. Bensing and M.G. Ausems, Cancer genetic counseling: communication and counselees' post-visit satisfaction, cognitions, anxiety, and needs fulfillment, J Genet Couns 16 (2007), pp. 85-96.

[41] A.H. Roshanai, R. Rosenquist, C. Lampic and K. Nordin, Does enhanced information at cancer genetic counseling improve counselees' knowledge, risk perception, satisfaction and negotiation of information to at-risk relatives? - a randomized study, Acta Oncol 48 (2009), pp. 999-1009.

[42] P. Roussi, K.A. Sherman, S. Miller, J. Buzaglo, M. Daly and A. Taylor et al., Enhanced counselling for women undergoing BRCA1/2 testing: impact on knowledge and psychological distress-results from a randomised clinical trial, Psychol Health 25 (2010), pp. 401-415.

[43] A. Karasz, M.D. McKee and K. Roybal, Women's experiences of abnormal cervical cytology: illness representations, care processes, and outcomes, Ann Fam Med 1 (2003), pp. 196-202.

[44] D.M. Eccles and G. Pichert, Familial non-BRCA1/BRCA2-associated breast cancer, Lancet Oncol 6 (2005), pp. 705-711.

[45] K. Offit and on behalf of the ASCO Working Group on Genetic Testing for Cancer Susceptibility, American Society of Clinical Oncology Policy Statement Update: genetic testing for cancer susceptibility, J Clin Oncol 21 (2003), pp. 2397-2406.

[46] A. Antoniou, P.D. Pharoah, S. Narod, H.A. Risch, J.E. Eyfjord and J.L. Hopper et al., Average risks of breast and ovarian cancer associated with BRCA1 or BRCA2 mutations detected in case Series unselected for family history: a combined analysis of 22 studies, Am J Hum Genet 72 (2003), pp. 11171130.

[47] A.H. van der Hout, A.M. van den Ouweland, R.B. van der Luijt, H.J. Gille, D. Bodmer and H. Bruggenwirth et al., A DGGE system for comprehensive mutation screening of BRCA1 and BRCA2: application in a Dutch cancer clinic setting, Hum Mutat 27 (2006), pp. 654-666.

[48] E.B. Claus, N. Risch and W.D. Thompson, Autosomal dominant inheritance of early-onset breast cancer. Implications for risk prediction, Cancer 73 (1994), pp. 643-651.

[49] The Dutch Institute for Healthcare Improvement (СВO), Guideline for breast cancer [Richtlijn mammacarcinoom] (2008) [accessed 06.07.10] 
Pieterse, A.H., Ausems, M.G.E.M., Spreeuwenberg, P., Dulmen, S. van. Longer-term influence of breast cancer genetic counseling on cognitions and distress: smaller benefits for affected versus unaffected women. Patient Education and Counseling: 2011, 85(3), 425-431

\section{[TABLES AND FIGURES]}

\section{Table 1}

BRCA1/2-test indication and test-result, counselor's estimate of counselee's lifetime breast cancer risk, and counselee risk perception accuracy by disease status and overall $(N=77)$.

\begin{tabular}{|c|c|c|c|c|c|c|}
\hline & \multicolumn{2}{|c|}{ Affected } & \multicolumn{2}{|c|}{ Unaffected } & \multicolumn{2}{|c|}{ Overall } \\
\hline & $N$ & $\%$ & $N$ & $\%$ & $N$ & $\%$ \\
\hline \multicolumn{7}{|l|}{ Indication for BRCA1/2-test ${ }^{\mathrm{a}}$} \\
\hline Yes & 37 & 84 & 15 & 46 & 52 & 68 \\
\hline No & 7 & 16 & 18 & 55 & 25 & 33 \\
\hline \multicolumn{7}{|l|}{ BRCA $1 / 2$-test result } \\
\hline BRCA $1 / 2$ positive & 5 & 11 & 2 & 6 & 7 & 9 \\
\hline BRCA1/2 negative $e^{b}$ & 0 & - & 2 & 6 & 2 & 3 \\
\hline Unclassified variant $^{c}$ & 6 & 14 & 1 & 3 & 7 & 9 \\
\hline Uninformative $^{d}$ & 24 & 55 & 7 & 21 & 31 & 40 \\
\hline Counselee declined testing & 2 & 5 & 0 & - & 2 & 3 \\
\hline Family member declined testing & 0 & - & 2 & 6 & 2 & 3 \\
\hline Family member(s) deceased & 0 & - & 1 & 3 & 1 & 1 \\
\hline DNA-test was not indicated & 7 & 16 & 18 & 55 & 25 & 33 \\
\hline \multicolumn{7}{|c|}{ Increased estimated lifetime breast cancer risk ${ }^{e}$} \\
\hline No $(<15 \%)$ & 14 & 32 & 7 & 21 & 21 & 27 \\
\hline Slightly (15-20\%) & 11 & 25 & 14 & 42 & 25 & 33 \\
\hline Moderately to highly (>20\%) & 19 & 43 & 12 & 36 & 31 & 40 \\
\hline \multicolumn{7}{|l|}{ Risk perception accuracy } \\
\hline \multicolumn{7}{|l|}{ Pre-counseling $\left(T_{0}\right)$} \\
\hline Underestimation & 9 & 23 & 1 & 3 & 10 & 14 \\
\hline Correct estimation ${ }^{f}$ & 1 & 3 & 0 & - & 1 & 1 \\
\hline Overestimation & 30 & 75 & 29 & 97 & 59 & 84 \\
\hline \multicolumn{7}{|l|}{ Immediately post-counseling $\left(T_{1}\right)$} \\
\hline Underestimation & 9 & 24 & 5 & 16 & 14 & 21 \\
\hline Correct estimation & 4 & 9 & 10 & 32 & 14 & 21 \\
\hline Overestimation & 24 & 55 & 16 & 52 & 40 & 59 \\
\hline \multicolumn{7}{|l|}{ Six-month post-counseling $\left(T_{2}\right)$} \\
\hline Underestimation & 6 & 14 & 8 & 24 & 14 & 19 \\
\hline Correct estimation & 3 & 7 & 6 & 18 & 9 & 13 \\
\hline Overestimation & 30 & 68 & 19 & 57 & 49 & 68 \\
\hline Total number of counselees & 44 & & 33 & & 77 & \\
\hline
\end{tabular}

Numbers do not add up to 77 due to missing values.

a Indication for BRCA1/2-testing in affected counselees or affected relative.

b BRCA1/2-negative test-results were conclusive in unaffected counselees when a mutation had been detected in an affected family member.

c Positive mutation for which it is unknown whether it concerns a pathogenic mutation or an innocent variant.

¿ No BRCA mutation detected.

' Counselors' estimates for counselees; extra surveillance is recommended for risk $>20 \%$

${ }^{\mathrm{f}}$ Correct estimation $=$ exact same risk as the risk estimated by the counselor.

Table 2

Changes in mean cognitions and distress from before to six months after counseling, controlled for total number of visits, number of 1 st-degree affected relatives, and BRCA $1 /$ 2-test indication.

\begin{tabular}{lccc}
\hline & $\begin{array}{l}\text { Pre-counseling }\left(T_{0}\right) \\
\mathrm{M}(95 \% \mathrm{Cl})\end{array}$ & $\begin{array}{l}\text { Immediate post-counseling }\left(T_{1}\right) \\
\mathrm{M}(95 \% \mathrm{Cl})\end{array}$ & $\begin{array}{l}\text { Six-month post-counseling }\left(T_{2}\right) \\
\mathrm{M}(95 \% \mathrm{Cl})\end{array}$ \\
\hline Cognitions (range scale) & & & $59(47-70)$ \\
Overestimation of risk & & $4.48(4.02-4.99)$ & $68(56-77)^{++}$ \\
Correct breast cancer knowledge (0-7) & $44(73-91)^{* * *}$ & $1.31(1.17-1.46)$ & $4.45(4.00-4.96)$ \\
Perceived personal control (0-2) & $1.09(0.98-1.21)^{* *}$ & $1.36(1.22-1.51)^{+++}$ \\
Distress (range scale) & & $19.88(17.94-21.82)^{* *}$ & $18.45(16.67-20.23)^{+++}$ \\
State-trait anxiety inventory (10-40) & $22.11(20.30-23.92)^{* *}$ & $20.32(17.35-23.30)$ & $17.85(14.91-20.80)$ \\
Impact of event scale (0-75) & $17.49(14.41-20.57)^{*+}$ & \\
\hline
\end{tabular}

a, confidence interval.

a, confidence interval.
a Scores show percentages of women who overestimated their risk of breast cancer.

$T_{0}$ versus $T_{1}: " p<0.05, \chi^{2} \geq 3.84,{ }^{* *} p<0.01, \chi^{2} \geq 6.64,{ }^{* * *} p<0.001, \chi^{2} \geq 10.83$.

$T_{1}$ versus $T_{2}: " p<0.05, \chi^{2} \geq 3.84$.
$T_{1}$.

$T_{0}$ versus $T_{2}:{ }^{+} p<0.01, \chi^{2} \geq 6.64,{ }^{+++} p<0.001, \chi^{2} \geq 10.83$. 
Pieterse, A.H., Ausems, M.G.E.M., Spreeuwenberg, P., Dulmen, S. van. Longer-term influence of breast cancer genetic counseling on cognitions and distress: smaller benefits for affected versus unaffected women. Patient Education and Counseling: 2011, 85(3), 425-431

Table 3

Changes in mean cognitions and distress from before to six months after counseling in affected versus unaffected counselees, controlled for total number of visits, number of 1st-degree affected relatives, and BRCA1/2-test indication.

\begin{tabular}{|c|c|c|c|}
\hline & $\begin{array}{l}\text { Pre-counseling }\left(T_{0}\right) \\
\mathrm{M}(95 \% \mathrm{Cl})\end{array}$ & $\begin{array}{l}\text { Immediate post-counseling }\left(T_{1}\right) \\
\mathrm{M}(95 \% \mathrm{CI})\end{array}$ & $\begin{array}{l}\text { Six-month post-counseling }\left(T_{2}\right) \\
\mathrm{M}(95 \% \mathrm{Cl})\end{array}$ \\
\hline \multicolumn{4}{|c|}{ Cognitions (range scale) } \\
\hline \multicolumn{4}{|c|}{ Overestimation of risk ${ }^{2}$} \\
\hline Affected & $76(60-87)$ & $67(50-81)$ & $77(60-88)$ \\
\hline Unaffected & $96(78-99)^{* * *}$ & $50(32-68)$ & $57(38-73)^{+++}$ \\
\hline \multicolumn{4}{|c|}{ Correct breast cancer knowledge (0-7) } \\
\hline Affected & $4.67(4.04-5.41)$ & $4.51(3.89-5.24)$ & $4.52(3.89-5.24)$ \\
\hline Unaffected & $4.83(4.08-5.72)$ & $4.44(3.72-5.29)$ & $4.36(3.66-5.20)^{+}$ \\
\hline \multicolumn{4}{|c|}{ Perceived personal control $(0-2)$} \\
\hline Affected & $1.14(0.99-1.29)$ & $1.25(1.06-1.44)$ & $1.29(1.10-1.48)$ \\
\hline Unaffected & $1.04(0.87-1.21)^{* *}$ & $1.41(1.19-1.63)$ & $1.47(1.25-1.68)^{+++}$ \\
\hline \multicolumn{4}{|c|}{ Distress (range scale) } \\
\hline \multicolumn{4}{|c|}{ State-trait anxiety inventory $(10-40)$} \\
\hline Affected & $22.04(19.74-24.35)$ & $20.74(18.28-23.21)$ & $19.58(17.35-21.82)^{+}$ \\
\hline Unaffected & $22.22(19.60-24.25)^{* * *}$ & $18.77(15.95-21.59)$ & $16.98(14.42-19.54)^{+++}$ \\
\hline \multicolumn{4}{|c|}{ Impact of event scale (0-75) } \\
\hline Affected & $18.47(14.28-22.65)^{* *}$ & $23.18(19.17-27.20)$ & $21.18(17.22-25.14)$ \\
\hline Unaffected & $16.20(11.31-21.09)$ & $16.56(11.90-21.23)$ & $13.65(9.10-18.20)$ \\
\hline
\end{tabular}

c, confidence interval.

a Scores show percentages of women who overestimated their risk of breast cancer.

$T_{0}$ versus $T_{1}: " * p<0.01, \chi^{2} \geq 6.64,{ }^{* * *} p<0.001, \chi^{2} \geq 10.83$.

$T_{0}$ versus $T_{2}:{ }^{+} p<0.05, \chi^{2} \geq 3.84,{ }^{++} p<0.01, \chi^{2} \geq 6.64 ;{ }^{+++} p<0.001, \chi^{2} \geq 10.83$.

\section{总}

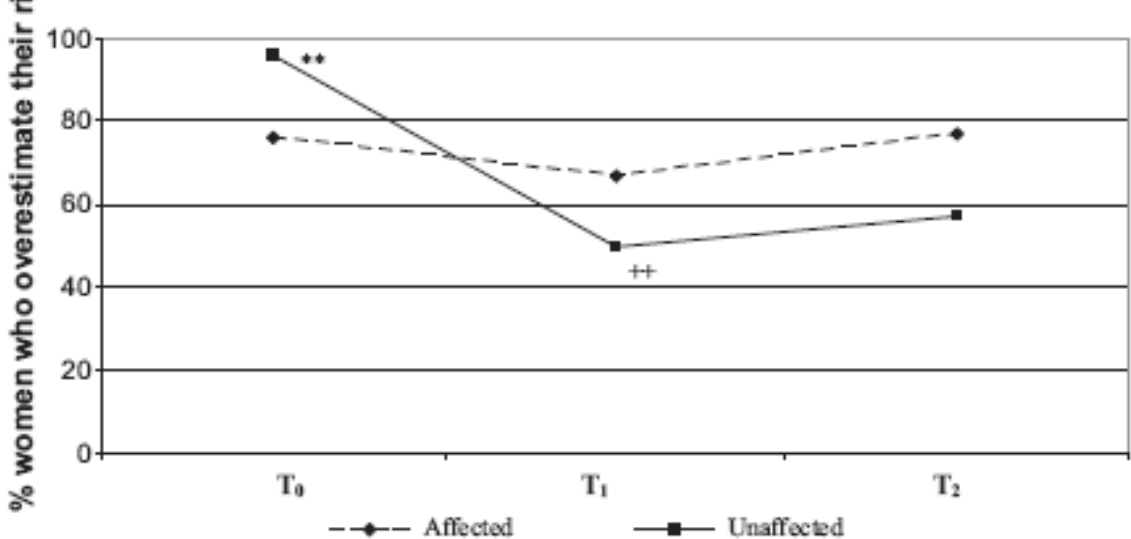

$T_{0}=$ pre-counseling; $T_{1}=$ immediately post-counseling; $T_{2}=$ six-month post-counseling

Significance of differences $T_{0}$ versus $T_{1}: * * p<.01, \chi^{2} \geq 6.64$

Significance of differences $T_{0}$ versus $T_{2}:++p<, 01, \chi^{2} \geq 6.64$

Fig. 1. Significance of difference in differences between risk perception accuracy scores between $T_{0}$ and $T_{1}$ and between $T_{0}$ and $T_{2}$, in affected versus unaffected counselees. $T_{0}=$ pre-counseling; $T_{1}=$ immediately post-counseling; $T_{2}=$ six-month post-counseling. Significance of differences $T_{0}$ versus $T_{1}$ : " $p<0.01, \chi^{2} \geq 6.64$. Significance of differences $T_{0}$ versus $T_{2}:{ }^{++} p<0.01, \chi^{2} \geq 6.64$. 
Pieterse, A.H., Ausems, M.G.E.M., Spreeuwenberg, P., Dulmen, S. van. Longer-term influence of breast cancer genetic counseling on cognitions and distress: smaller benefits for affected versus unaffected women. Patient Education and Counseling: 2011, 85(3), 425-431

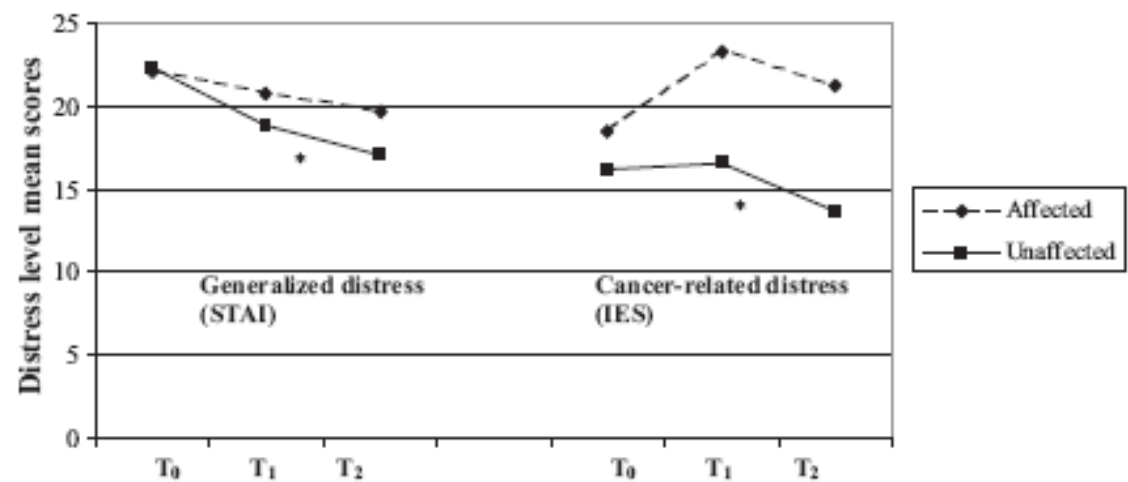

IES-Impact of event scale; STAI-State-trait anxiety

$\mathrm{T}_{0}$-pre-counseling, $\mathrm{T}_{1}$-immediately post-counseling; $\mathrm{T}_{2}$-six-month post-counseling

Significance of differences $\mathrm{T}_{0}$ versus $\mathrm{T}_{2}:+\mathrm{p}<.05, \chi 2 \geq 3.84$

Fig. 2. Significance of difference in differences between mean distress levels between $T_{0}$ and $T_{1}$ and between $T_{0}$ and $T_{2}$, in affected versus unaffected counselees. IES = Impact of event scale; STAI =State-trait anxiety. $T_{0}=$ pre-counseling; $T_{1}=$ immediately post-counseling; $T_{2}=$ six-month post-counseling. Significance of differences $T_{0}$ versus $T_{2}:{ }^{+} p<0.05, \chi^{2} \geq 3.84$. 